\title{
Phosphorothioate oligonucleotides, suramin and heparin inhibit DNA-dependent protein kinase activity
}

\author{
Y Hosoi ${ }^{* 1,3}$, Y Matsumoto', M Tomita', A Enomoto', A Morita', K Sakai', N Umeda', H-J Zhao ${ }^{3}$, \\ K Nakagawa ${ }^{2}$, T Ono ${ }^{3}$ and $N$ Suzuki'
}

'Department of Radiation Oncology, Faculty of Medicine, University of Tokyo, Tokyo, Japan; ${ }^{2}$ Department of Radiology, Faculty of Medicine, University of Tokyo, Tokyo, Japan; ${ }^{3}$ Department of Radiation Research, Tohoku University School of Medicine, Sendai, Japan; ${ }^{4}$ Low Dose Radiation Research Center, Central

Research Institute of Electric Power Industry, Tokyo, Japan

\begin{abstract}
Phosphorothioate oligonucleotides and suramin bind to heparin binding proteins including DNA polymerases, and inhibit their functions. In the present study, we report inhibition of DNA-dependent protein kinase activity by phosphorothioate oligonucleotides, suramin and heparin. Inhibitory effect of phosphorothioate oligonucleotides on DNA-dependent protein kinase activity was increased with length and reached a plateau at 36-mer. The base composition of phosphorothioate oligonucleotides did not affect the inhibitory effect. The inhibitory effect by phosphorothioate oligodeoxycytidine 36-mer can be about 200-fold greater than that by the phosphodiester oligodeoxycytidine 36-mer. The inhibitory effect was also observed with purified DNA-dependent protein kinase, which suggests direct interaction between DNA-dependent protein kinase and phosphorothioate oligonucleotides. DNA-dependent protein kinase will have different binding positions for double-stranded DNA and phosphorothioate oligodeoxycytidine 36-mer because they were not competitive in DNA-dependent protein kinase activation. Suramin and heparin inhibited DNA-dependent protein kinase activity with $I C_{50}$ of $1.7 \mu \mathrm{M}$ and $\left.0.27 \mu \mathrm{g} \mathrm{ml}\right|^{-1}$ respectively. DNA-dependent protein kinase activities and DNA double-stranded breaks repair in cultured cells were significantly suppressed by the treatment with suramin in vivo. Our present observations suggest that suramin may possibly result in sensitisation of cells to ionising radiation by inactivation of DNA-dependent protein kinase and the impairment of double-stranded breaks repair.
\end{abstract}

British Journal of Cancer (2002) 86, I I43- I |49. DOl: 10.1038/sj/bjc/6600 I9 I www.bjcancer.com

(c) 2002 Cancer Research UK

Keywords: DNA-PK; phosphorothioate oligonucleotides; suramin; radiation sensitivity; DNA double-stranded breaks

Phosphorothioate oligonucleotide (S-oligo) is an analogue of phosphodiester oligonucleotide having modified internucleotide linkages that make it more stable to nucleases than phosphodiester oligonucleotide (Wagner, 1995). Antisense S-oligo is designed to have the complementary base sequence for binding the target mRNA specifically. However, the ability of S-oligo to bind nonspecifically to a variety of proteins has been well documented (Yakubov et al, 1993; Stein 1995). Such proteins include heparinbinding proteins such as basic fibroblast growth factor (bFGF), acid fibroblast growth factor (aFGF), Kaposi's growth factor (FGF-4) (Guvakova et al, 1995), and DNA polymerases (Gao et al, 1992). S-oligo also inhibits the functions of other proteins such as CD4 (Yakubov et al, 1993), gp120 (Stein et al, 1991), Mac-1 (Benimetskaya et al, 1997), RNase H (Gao et al, 1992), human immunodeficiency virus type 1 (HIV-1) reverse transcriptase (Marshall et al, 1992), herpes simplex virus (HSV) type 2-induced DNA polymerase (Gao et al, 1989), and HIV-1 integrase (Tramontano et al, 1998).

*Correspondence: Y Hosoi, Department of Radiation Oncology, Faculty of Medicine, University of Tokyo, 7-3-I Hongo, Bunkyoku, Tokyo I I3-0033, Japan; E-mail: hosoi@m.u-tokyo.ac.jp

Received 30 October 2000; revised 8 November 200I; accepted 6 December 2001
Suramin has been used as an anti-cancer agent and an anti-HIV agent (Stein, 1993). The structure of suramin is shown in Figure 1. Potential mechanisms of the anti-tumour effect are inhibition of heparin binding growth factors. Suramin binds to PDGF, basic fibroblast growth factor (bFGF) and other growth factors, and it prevents the binding of growth factors to their corresponding receptors (Hosang, 1985; Coffey et al, 1987; Stein, 1993). Potential mechanisms of the anti-HIV effect are inactivation of reverse transcriptase and DNA polymerases (Mitsuya et al, 1984; Spigelman et al, 1987; Stein, 1993). Suramin is also an inhibitor of Protein kinase C and DNA topoisomerase II (Mahoney et al, 1990; Bojanowski et al, 1992).

Thus both S-oligo and suramin act as heparin mimetics and they inhibit HIV-1 integration into host DNA (Stein et al, 1993; Benimetskaya et al, 1995). In the present study, we investigated the effects of S-oligo, suramin and heparin on activity of DNAdependent protein kinase (DNA-PK) because DNA-PK is thought to be a heparin binding protein (Lees-Miller and Anderson, 1991) and because it is involved in the retroviral integration into host DNA (Daniel et al, 1999). We demonstrate that S-oligo, suramin and heparin inhibit DNA-PK activity. DNA-dependent protein kinase activities and DNA-double stranded breaks (DSBs) repair of cultured cells were significantly suppressed by the treatment with suramin. Our present observations suggest that suramin may possibly result in sensitisation of cells to ionising radiation by inactivation of DNA-PK and the impairment of DSBs repair. 


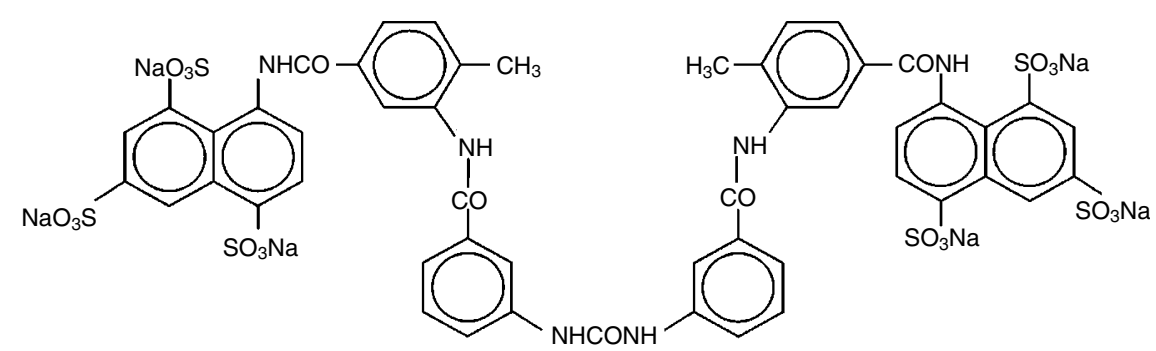

Figure I Structure of suramin. The hexasodium salt is shown. The molecular weight of suramin is 1429 .

\section{MATERIALS AND METHODS}

\section{Cell lines}

LM217 is an SV-40 transformed human fibroblast cell line derived from HS27 (Murnane, 1986), and it was obtained from Dr JP Murnane. A human glioblastoma cell line T98G, and a human acute lymphoblastic leukaemia cell line MOLT-4 were obtained from the ATCC (Rockville, MD, USA).

\section{Chemicals}

Suramin was purchased from Calbiochem-Novabiochem Co. (La Jolla, CA, USA). Oligonucleotides were synthesised by standard phosphoramidite chemistry (Hokkaido System Science Co., Sapporo, Japan). The oligonucleotides were base-deblocked in $30 \%$ ammonium hydroxide at $55^{\circ} \mathrm{C}$ for $8 \mathrm{~h}$ and purified by reversed phase high pressure liquid chromatography (HPLC) $(0.1 \mathrm{M}$ triethylamine). The oligonucleotides were detritylated in $80 \%$ acetic acid, lyophilised and resuspended in 50\% diethyl ether. The aqueous phase was recovered and the oligonucleotides were precipitated. Oligonucleotide concentrations were determined by spectroscopy. The sizes of oligonucleotides were confirmed by polyacrylamide gel electrophoresis. Phosphorothioate oligodeoxycytidine with different chain length $(\mathrm{S}-\mathrm{dCn})$, phosphorothioate oligodeoxyguanosine 36-mer $\left(\mathrm{S}-\mathrm{dG}_{36}\right)$, phosphorothioate oligodeoxythymidine 36-mer $\left(\mathrm{S}-\mathrm{dT}_{36}\right)$, phosphorothioate oligodeoxyadenosine 36-mer $\left(\mathrm{S}-\mathrm{dA}_{36}\right)$, and phosphodiester oligodeoxycytidine 36-mer $\left(\mathrm{dC}_{36}\right)$ were synthesised.

\section{Digestion of S- $\mathrm{dC}_{36}$}

For digestion of $\mathrm{S}-\mathrm{dC}_{36}$, it was incubated in $2 \mathrm{~N} \mathrm{HCl}$ at $95^{\circ} \mathrm{C}$ for $1 \mathrm{~h}$. After incubation, $\mathrm{pH}$ of the solution was adjusted to $\mathrm{pH} 7.2$ using $\mathrm{NaOH}$. The effect of the $\mathrm{HCl}$-treatment was confirmed by polyacrylamide gel electrophoresis and no obvious band was observed.

\section{DNA-PK purification}

DNA-dependent protein kinase was purified as described previously (Matsumoto et al, 1997). MOLT-4 cell nuclei were prepared from $2-5 \times 10^{9}$ cells as described by Dignam et al (1983). The nuclei were resuspended in buffer A $(20 \mathrm{~mm}$ HEPES-NaOH, pH 7.9; $400 \mathrm{mM} \mathrm{KCl} ; 1$ mM EDTA; 1 mM EGTA; $0.02 \%$ Tween 20; $10 \%$ glycerol; $1 \mathrm{mM}$ dithiothreitol (DTT); $1 \mathrm{mM}$ phenylmethylsulfonyl fluoride (PMSF); $1 \mu \mathrm{g} \mathrm{ml}^{-1}$ of leupeptin, pepstatin and antipain, respectively) and agitated with a stirring bar for $30 \mathrm{~min}$ followed by centrifugation at $100000 \mathrm{~g}$ for $60 \mathrm{~min}$. The supernatant nuclear extract was passed through the first DEAE Bio-Gel A (Bio-Rad Laboratories, Hercules, CA, USA) column and dialysed against buffer B (20 mM Tris- $\mathrm{HCl}$, pH 7.5; 1 mM EDTA; $10 \%$ glycerol; $50 \mathrm{~mm} \mathrm{NaCl;} 1 \mathrm{~mm}$ DTT; $1 \mathrm{mM}$ PMSF; $1 \mu \mathrm{g} \mathrm{ml}^{-1}$ leupeptin; $1 \mu \mathrm{g} \mathrm{ml}^{-1}$ pepstatin; $1 \mu \mathrm{g} \mathrm{ml}^{-1}$ antipain). Dialysate was applied to the second DEAE
Bio-Gel A and eluted with buffer $\mathrm{B}$ with increasing $\mathrm{NaCl}$ concentration linearly from 0.05 to $0.3 \mathrm{M}$. DNA-dependent protein kinase was eluted with $0.14-0.17 \mathrm{M} \mathrm{NaCl}$. The DNA-PK fractions were passed through NAP-25 column (Amersham Pharmacia Biotech, Uppsala, Sweden) equilibrated with buffer C (20 mM HEPES$\mathrm{NaOH}$, pH $7.2 ; 1 \mathrm{mM} \mathrm{MgCl} ; 15 \%$ glycerol; $200 \mathrm{mM} \mathrm{NaCl} ; 1 \mathrm{mM}$ DTT; $1 \mathrm{mM}$ PMSF; $1 \mu \mathrm{g} \mathrm{ml}^{-1}$ leupeptin; $1 \mu \mathrm{g} \mathrm{ml}^{-1}$ pepstatin, $1 \mu \mathrm{g} \mathrm{ml}^{-1}$ antipain) and finally loaded to a native DNA-cellulose column (Amersham Pharmacia Biotech). Absorbed protein was eluted into 12 fractions $(1 \mathrm{ml}$ each) by stepwise increase of $\mathrm{NaCl}$ concentration in buffer C. We used $0.6 \mathrm{M} \mathrm{NaCl}$ eluate as the purified DNA-PK holoenzyme. Final protein concentration of purified DNA-PK solution was $0.4 \mathrm{mg} \mathrm{ml}^{-1}$.

\section{DNA-PK activity measurement}

DNA-dependent protein kinase activity was assayed as previously described using a synthetic peptide (EPPLSQEAFADLWKK) (Hosoi et al, 1998b). Whole cell extracts were prepared as described previously (Hosoi et al, 1998a). The cell extracts were incubated in $20 \mu \mathrm{l}$ of kinase buffer $(20 \mathrm{~mm}$ HEPES-NaOH, pH 7.2; $100 \mathrm{~mm}$ $\mathrm{KCl} ; 5 \mathrm{mM} \mathrm{MgCl}$; $1 \mathrm{mM}$ DTT; $0.5 \mathrm{mM} \mathrm{NaF} ; 0.5 \mathrm{mM} \beta$-glycerophosphate; $0.2 \mathrm{mM}$ ATP; $10 \mu \mathrm{Ci} \mathrm{ml} \mathrm{ml}^{-1}\left[\gamma_{-}{ }^{32} \mathrm{P}\right] \mathrm{ATP}$ in the presence of $0.5 \mu \mathrm{g} \mathrm{ml}^{-1}$ Poly $(\mathrm{dG}-\mathrm{dC}) \cdot \operatorname{Poly}(\mathrm{dG}-\mathrm{dC})$ (Amersham Pharmacia Biotech) and $0.5 \mathrm{mg} \mathrm{ml}^{-1}$ substrate peptide) at $37^{\circ} \mathrm{C}$ for $15 \mathrm{~min}$. The final protein concentration in the reaction buffer was $0.15 \mathrm{mg} \mathrm{ml}^{-1}$. In DNA-PK activity measurement using the purified DNA-PK solution, $0.25 \mu \mathrm{l}$ of the solution was used in each reaction. The reactions were stopped by the addition of $20 \mu \mathrm{l}$ of $30 \%$ acetic acid and spotted onto P81 paper disks (Whatman International Ltd., Maidstone, UK). The disks were washed four times in $15 \%$ acetic acid. Radioactivity in the paper disks was measured in a liquid scintillation counter. The DNA-PK activity is defined as the amount of P transferred from ATP to the synthetic peptide in the reaction. The specific activities of the cell extracts from LM217 cells, those from T98G cells and the purified DNA-PK solution were $19.0 \pm 2.7,72.31 \pm 9.48$ and $2316.0 \pm 128.9 \mathrm{pmol}_{\mu \mathrm{g}}{ }^{-1}$ protein respectively.

\section{Preparation of plug and irradiation}

Cells in dishes were irradiated on ice using an X-ray machine SHIMADZU HF350C (Shimadzu Corporation, Kyoto, Japan) at $200 \mathrm{kV}, 20 \mathrm{~mA}$ with a $0.5 \mathrm{~mm} \mathrm{Cu}$ and $1.0 \mathrm{~mm}$ Al filter at a dose rate of $1.5 \mathrm{~Gy} \mathrm{~min}-1$, and then incubated in a $\mathrm{CO}_{2}$ incubator at $37^{\circ} \mathrm{C}$ for repair. At each paoin, cells were trypsinised and washed two times with cold PBS, and the resulting cell pellet was embedded in $0.75 \%$ agarose (Low Melt Preparative Grade Agarose, Bio-Rad Laboratories). These agarose sample plugs were immersed in ice-cold lysis solution ( $0.5 \mathrm{M}$ EDTA; $0.01 \mathrm{M}$ Tris; $2 \%$ Sarcosyl; $0.2 \mathrm{mg} \mathrm{ml}^{-1}$ proteinase $\mathrm{K}$ ) for $1 \mathrm{~h}$ and then incubated at $50^{\circ} \mathrm{C}$ for $48 \mathrm{~h}$. After lysis, sample plugs were washed for $1 \mathrm{~h}$ at room temperature in a buffer containing $10 \mathrm{~mm}$ Tris ( $\mathrm{pH} \mathrm{8.0)}$ and $0.1 \mathrm{M}$ EDTA and then treated for $1 \mathrm{~h}$ at $37^{\circ} \mathrm{C}$ in the same buffer with $0.1 \mathrm{mg} \mathrm{ml}^{-1}$ RNase A (Wang et al, 2001). For the initial time 
$(0 \mathrm{~h})$, cells were embedded in agarose and irradiated in ice-cold PBS followed by an immediate lysis as described (Okayasu et al, 1998).

\section{Pulsed-field gel electrophoresis (PFGE)}

Sample plugs were electrophoresed in $0.5 \times$ TBE buffer $(45 \mathrm{mM}$ Tris; $45 \mathrm{~mm}$ boric acid; $1.5 \mathrm{~mm}$ EDTA, $\mathrm{pH} 8.2)$ in a clamped homogenous electric field (CHEF) gel box (CHEF-DR ${ }^{\mathbb{B}}$ III System, Bio-Rad Laboratories) in $0.8 \%$ agarose gel (SeaKem GTG ${ }^{\mathbb{R}}$ agarose, Bio Whittaker Molecular Applications, ME, USA) at $14^{\circ} \mathrm{C}$.
The voltage applied was $6.0 \mathrm{~V} / \mathrm{cm}$ with a 60 -s pulse time for the first $9 \mathrm{~h}$ followed by 120 -s pulse time for the last $15 \mathrm{~h}$ (total run time $24 \mathrm{~h}$ ) (Okayasu et al, 1998). After electrophoresis, the gels were stained with ethidium bromide $\left(1.0 \mathrm{mg} \mathrm{ml}^{-1}\right)$, detained in deionised distilled water (Longo et al, 1997). The images were acquired under UV light using Printgraph AE-6910CX and ImageSaver AE-6905C (ATTO Corporation, Tokyo, Japan) and analysed by NIH image. Fraction of DNA in the lane (FDL) was calculated as $[$ (average density in the lane) $\times$ (area of the lane $)] /[$ (average density in the lane $) \times($ area of the lane $)+($ average density in the well $) \times($ area of the well $)]$. The background FDL, which corre-
A

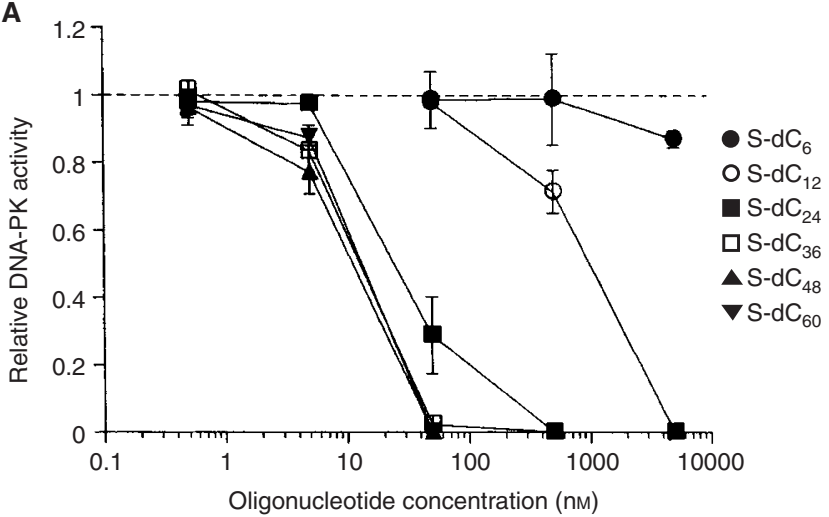

C

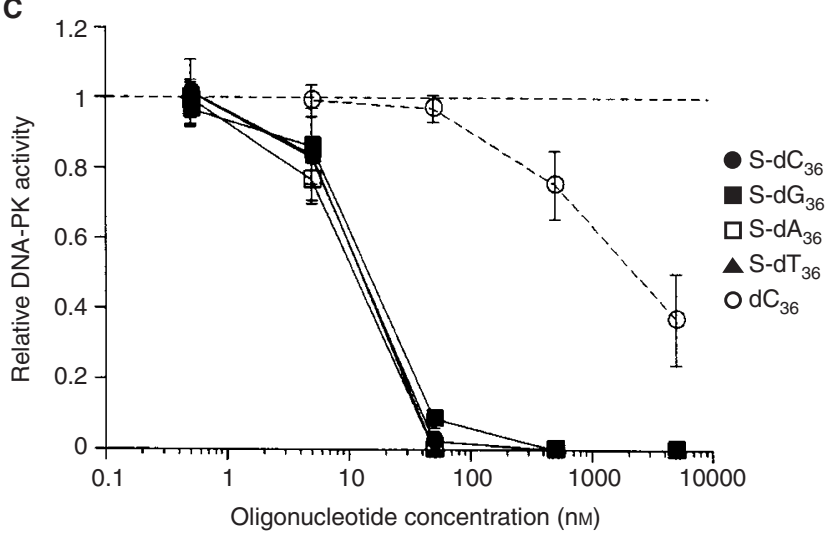

B

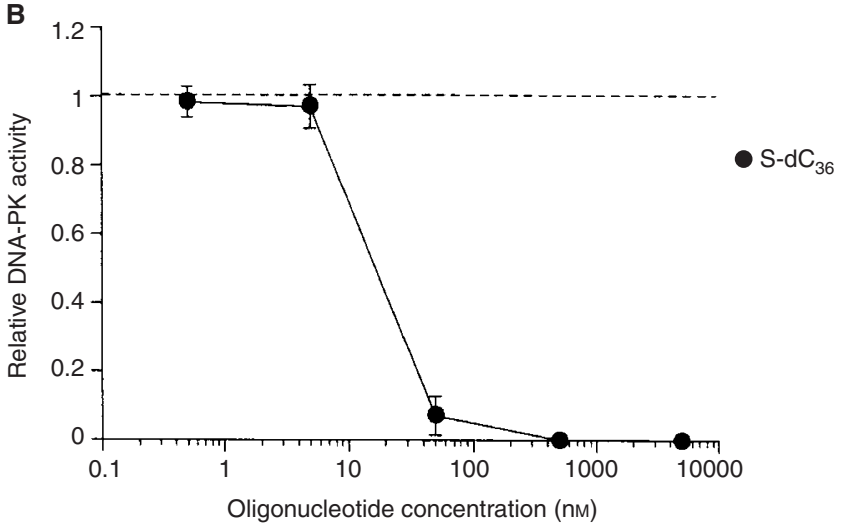

D

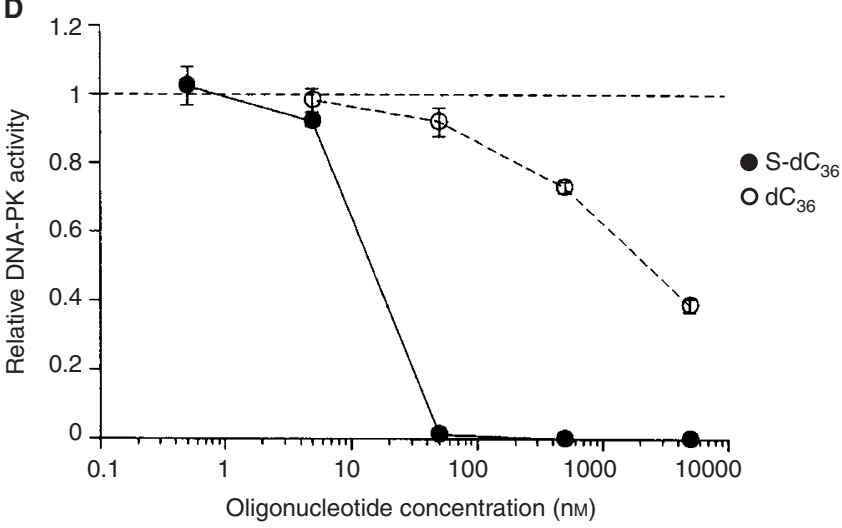

E

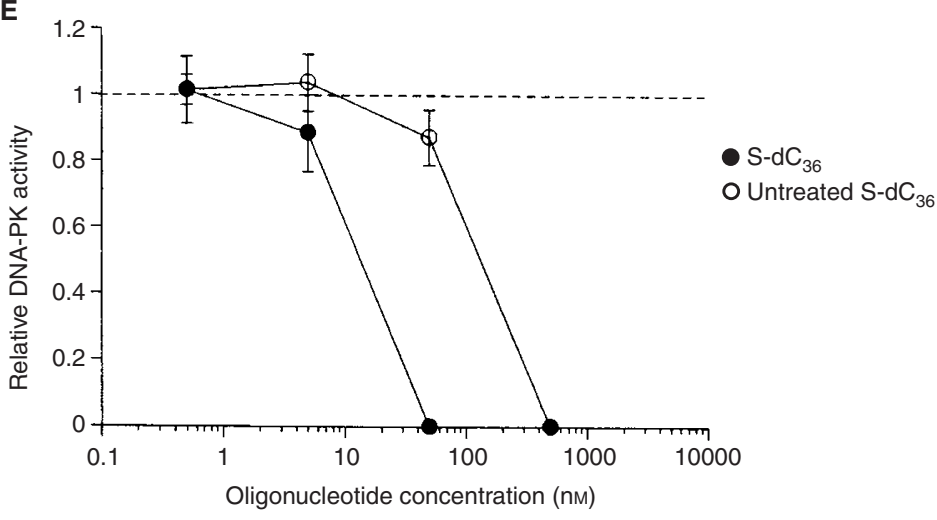

Figure 2 Effect of oligonucleotides on DNA-PK activity. (A) Effect of S-dC $6, \mathrm{~S}-\mathrm{dC} \mathrm{C}_{12}, \mathrm{~S}-\mathrm{dC}_{24}, \mathrm{~S}-\mathrm{dC} \mathrm{C}_{36}, \mathrm{~S}-\mathrm{dC} \mathrm{C}_{48}$, and S-dC 60 on DAN-PK activity. Whole cell extract prepared from LM217 was used. (B) Effect of S-dC 36 on DNA-PK activity. Whole cell extract prepared from T98G was used. (C) Effect of S-dC 36 , $\mathrm{S}-\mathrm{dG}_{36}, \mathrm{~S}-\mathrm{dA}_{36}, \mathrm{~S}-\mathrm{dT}_{36}$, and $\mathrm{dC}_{36}$ on DNA-PK activity. Whole cell extract prepared from LM217 was used. (D) Effect of S-dC 36 and dC $\mathrm{dC}_{36}$ on DNA-PK activity. Purified DNA-PK was used. (E) Effect of HCl-treated $\mathrm{S}-\mathrm{dC}_{36}$ and untreated $\mathrm{S}-\mathrm{dC}_{36}$ on DNA-PK activity. Whole cell extract prepared from $\mathrm{LM} 217$ was used. Salt concentration of untreated $\mathrm{S}-\mathrm{dC}_{36}$ was adjusted to that of $\mathrm{HCl}$-treated $\mathrm{S}-\mathrm{dC}_{36}$. DNA-PK activities are expressed as values relative to that of control, which is set to a value of I. The data represents the means \pm s.d. $(n=3)$. 
sponds to FDL without irradiation, was subtracted from each point.

\section{RESULTS}

Inhibition of DNA-PK activity was dependent on the chain length of S-dCn

DNA-dependent protein kinase activity was measured in the presence of S-dCn with different chain lengths. DNA-dependent protein kinase activity was inhibited by $\mathrm{S}-\mathrm{dCn}$ depending on the concentration of $\mathrm{S}-\mathrm{dCn}$ and the number of phosphorothioate linkages (Figure 2A). Inhibitory concentration $50\left(\mathrm{IC}_{50}\right)$ of S-dCn is shown in Figure 3. The $\mathrm{IC}_{50}$ value decreased from $975 \mathrm{~nm}$ to $13 \mathrm{nM}$ with the increased chain length from 12 to 36 . The $\mathrm{IC}_{50}$ value reached a plateau with the 36-mer. To confirm whether this inhibitory effect was specific for $\mathrm{LM} 217$, the effect of $\mathrm{S}-\mathrm{dC}_{36}$ on DNA-PK activity was investigated using whole cell extract derived from T98G. The $\mathrm{IC}_{50}$ in a T98G cell extract was almost the same as that in a LM217 cell extract (Figure 2B).

\section{Inhibition of DNA-PK activity was independent of the base composition}

Next, effect of base composition on inhibition of DNA-PK activity was investigated. Effect of $\mathrm{S}-\mathrm{dC}_{36}, \mathrm{~S}-\mathrm{dG}_{36}, \mathrm{~S}-\mathrm{dA}_{36}$, or $\mathrm{S}-\mathrm{dT}_{36}$ on DNA-PK activity is shown in Figure 2C. Inhibition of DNA-PK activity was not affected by the base composition of phosphorothioate 36-mer oligonucleotides.

Direct interaction between oligonucleotides and DNA-PK, and comparison between the effect of phosphodiester oligonucleotides on DNA-PK and that of phosphorothioate oligonucleotides

In order to confirm whether inhibition of DNA-PK activity by Soligos is mediated by direct interaction with DNA-PK, purified DNA-PK was used. $\mathrm{S}-\mathrm{dC}_{36}$ inhibited purified DNA-PK activity with the same $\mathrm{IC}_{50}$ as cell extracts, which is suggesting direct interaction between $\mathrm{S}-\mathrm{dC}_{36}$ and DNA-PK (Figure 2D). Next, the effect of $\mathrm{dC}_{36}$ on DNA-PK was compared with the effect of $\mathrm{S}-\mathrm{dC}_{36}$. DNA-dependent protein kinase activity was inhibited by $\mathrm{dC}_{36}$ (Figure 2C). However, $\mathrm{dC}_{36}$ showed much less inhibition than $\mathrm{S}$ $\mathrm{dC}_{36}$. The $\mathrm{IC}_{50}$ of $\mathrm{dC}_{36}$ was about 200 times higher than that of

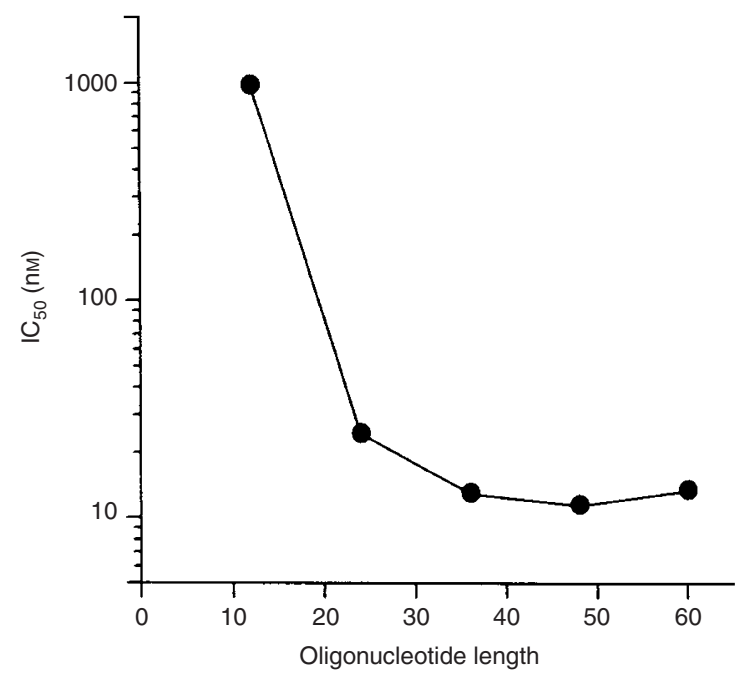

Figure 3 Dose-response curve after treatment with $\mathrm{S}-\mathrm{dCn}$. IC $\mathrm{C}_{50}$ was calculated from the data used for Figure 2A.
S- $\mathrm{dC}_{36}$. Similar inhibition was observed with purified DNA-PK (Figure 2D).

\section{Inhibition of DNA-PK activity by $S-\mathrm{dC}_{36}$ was not due to} chemical contaminants

The $\mathrm{IC}_{50}$ of $\mathrm{S}-\mathrm{dCn}$ was not linearly proportional to the chain length (Figure 3), which suggests that the inhibition was not due to contaminants in the purified phosphorothioate oligonucleotides. To confirm this, $\mathrm{S}-\mathrm{dC}_{36}$ was digested with $\mathrm{HCl}$ treatment at $95^{\circ} \mathrm{C}$ for $1 \mathrm{~h}$ and the effect of digested $\mathrm{S}-\mathrm{dC}_{36}$ on DNA-PK was investigated. $\mathrm{HCl}$-treatment decreased the $\mathrm{IC}_{50}$ value, which is indicating that the inhibition was not due to chemical contaminants (Figure 2E).

\section{S-dC ${ }_{36}$ did not compete with dsDNA for inhibition of DNA-PK activity}

Single-stranded DNA has been reported to inhibit DNA-PK activity by binding to DNA-PK at a different site from the dsDNA-binding site (Leuther et al, 1999). To gain insight into whether the S- $\mathrm{dC}_{36^{-}}$ binding site differs from the dsDNA-binding site, we investigated whether dsDNA competes with $\mathrm{S}-\mathrm{dC}_{36}$ in DNA-PK activation. DNA-dependent protein kinase activation by dsDNA reached its maximal level at a concentration of $0.5 \mu \mathrm{g} \mathrm{m} l^{-1}$, remaining unchanged as the concentration increased up to $5 \mu \mathrm{g} \mathrm{ml}^{-1}$ (Figure 4). Inhibition of DNA-PK activity by $50 \mathrm{nM} \mathrm{S}-\mathrm{dC}_{36}$ was unaffected by change in dsDNA concentration (Figure 4). This non-competitive inhibition suggests that the $\mathrm{S}-\mathrm{dC}_{36}$-binding site is distinct from the dsDNA-binding site.

\section{Inhibition of DNA-PK activity by suramin and heparin}

Effects of suramin and heparin on DNA-PK activity in cell extracts are shown in Figure 5A,B. Suramin and heparin suppressed DNAPK activity with $\mathrm{IC}_{50}$ of $1.7 \mu \mathrm{M}$ and $0.27 \mu \mathrm{g} \mathrm{ml}^{-1}$ respectively.

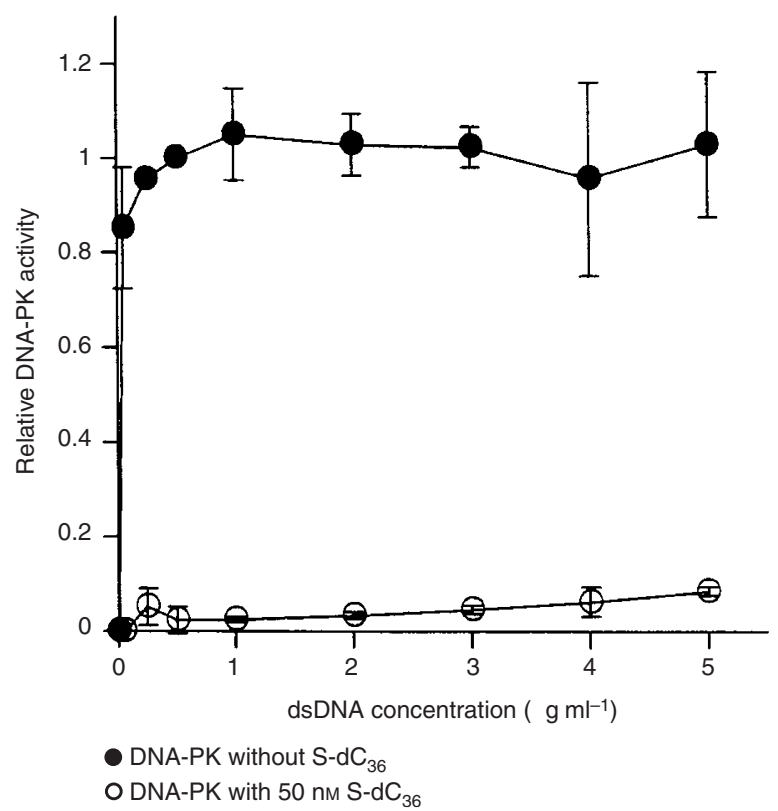

Figure 4 Effect of dsDNA concentration on inhibition of DNA-PK activity by $\mathrm{S}-\mathrm{dC}_{36}$. Concentrations of dsDNA ranged from $0.05 \mu \mathrm{g} \mathrm{ml} \mathrm{l}^{-1}$ to $5 \mu \mathrm{g} \mathrm{ml} l^{-1}$. Whole cell extract prepared from LM2 17 was used. Details are the same as shown in Figure 2. Figure 5. Effect of suramin $(\mathbf{A})$ and heparin (B) on DNA-PK activity. Whole cell extract prepared from LM217 was used. Details are the same as shown in Figure 2. 
A

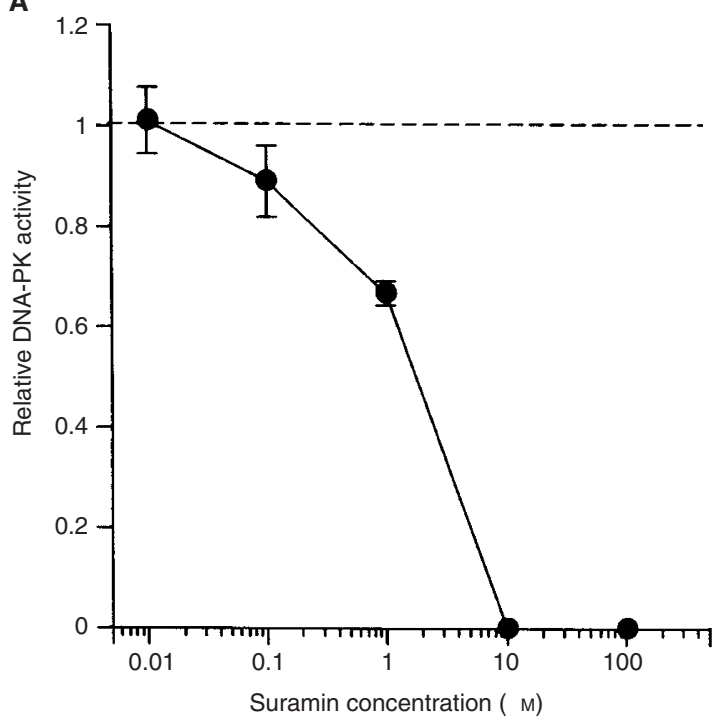

B

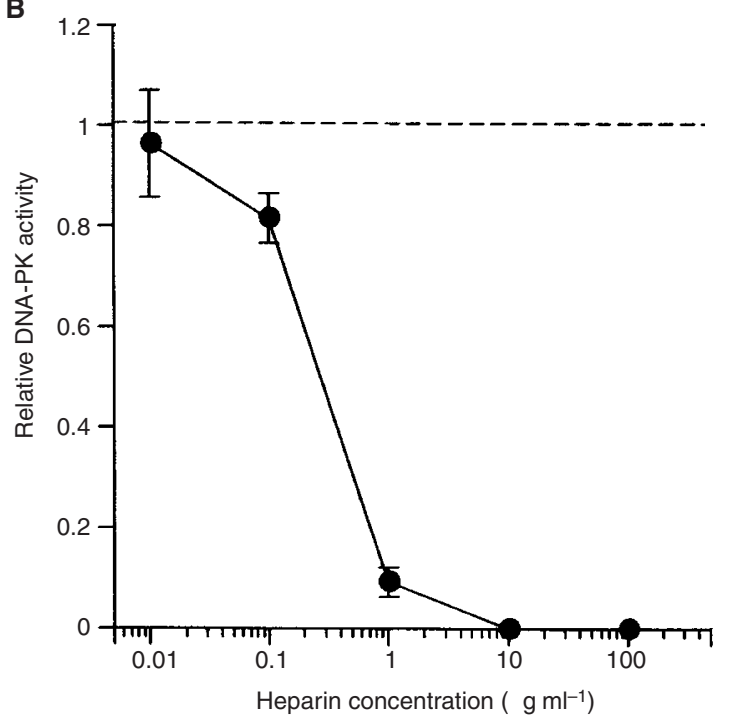

Figure 5 Effect of suramin (A) and heparin (B) on DNA-PK activity. Whole cell extract prepared from LM217 was used. Details are the same as shown in Figure 2.

Next, we investigated effects of suramin on DNA-PK activity in cultured cells. LM217 cells at growth phase were treated with $1 \mathrm{~mm}$ suramin for $20 \mathrm{~h}$. After treatment, cells were washed with PBS three times, total cell extracts were prepared, and DNA-PK activities were measured. DNA-PK activities were significantly suppressed by the treatment with suramin to $80.7 \pm 8.7 \%$ of the control value $(P=0.045)$. The treatment with $1 \mathrm{mM}$ suramin for $24 \mathrm{~h}$ did not affect the plating efficiency of LM217 cells (data not shown).

\section{Inhibition of DNA repair by suramin}

Because treatment with $1 \mathrm{~mm}$ suramin in vivo suppressed DNA-PK activity to $80.7 \%$ of the control value, we investigated the effect of suramin on DNA-repair after irradiation. After $20 \mathrm{~h}$ treatment with $1 \mathrm{mM}$ suramin, LM217 cells were irradiated with $50 \mathrm{~Gy}$, and DSBs repair was analysed by PFGE. The FDL is reported to be proportional to the ratio of fragmented double-stranded DNA (Okayasu et al, 1998). Although the initial DSBs $(0 \mathrm{~h})$ with $50 \mathrm{~Gy}$ irradiation was statistically identical for suramin-treated and untreated cells, the significant inhibition of DSBs repair was observed in samples treated with suramin (Figure 6).

\section{DISCUSSION}

S-oligos bind sequence-independently to a variety of proteins and inhibit their functions (Stein, 1995). S-oligos act as heparin mimetics and they bind to heparin binding proteins such as bFGF (Benimetskaya et al, 1995). Furthermore, S-oligos inhibit HIV-1 DNA integration (Matsukura et al, 1987; Agrawal et al, 1988). In these respects, S-oligos resemble such polyanions as suramin and pentosan polysulphate (Stein, 1995). Suramin and pentosan polysulphate also bind to heparin binding proteins and inhibit HIV-1 DNA integration (Mitsuya et al, 1984; Zugmaier et al, 1992; Stein, 1993). In the present study, we demonstrated that both S-oligos and suramin show the same effects on DNA-PK activity.

Binding of S-oligos to heparin binding proteins is sequenceindependent but is dependent on the chain length of S-oligos. It has been reported that S-oligos with a chain length longer than 15 could bind and inhibit the proteins, and that the inhibitory effect reached a plateau level with a chain length of 28 (Gao et al, 1992; Marshall et al, 1992). In the present study, we reported that the inhibitory effect of S-oligos on DNA-PK activity is sequence-independent and is dependent on the chain length. The inhibitory effect reached a plateau level with a chain length of 36, which is almost the same length as previously reported. Marshall et al (1992) reported that the inhibitory effect of oligonucleotides on HIV-1 reverse transcriptase could be at least 30 -fold greater with phosphorodithioate oligonucleotides, which have two sulphur at each site of internucleotide linkages, than with phosphorothioate oligonucleotides. Benimetskaya et al (1995) reported that binding of phosphorothioate oligonucleotides to proteins is independent on P-chirality at the internucleotide linkage sites.

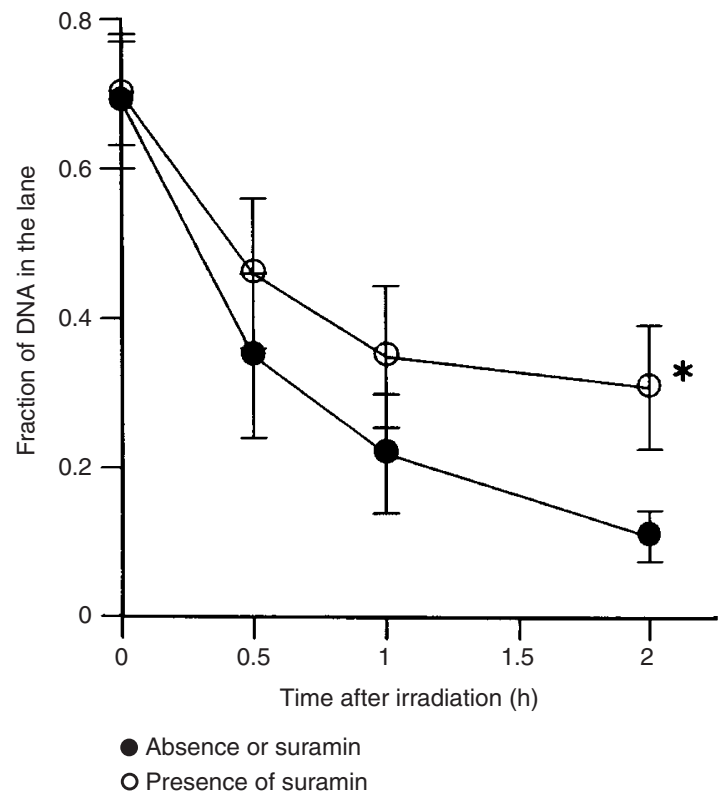

Figure 6 Kinetics of DNA double strand breaks after 50 Gy irradiation in exponentially growing LM2I7 cells in the presence or absence of I mM suramin. Cells were treated with suramin $20 \mathrm{~h}$ before irradiation and the drug was kept in the medium during the post-irradiation repair period. The data represent the means \pm s.d. $(n=3)$. ${ }^{*} P<0.05$. 
These results may suggest that substances having the similar structure to polyanions with sulphur bind heparin-binding proteins and inhibit their functions (Zugmaier et al, 1992; Guvakova et al, 1995).

Phosphorothioate oligonucleotides contain a sulphur atom at each phosphorus atom. Each $n$-mer phosphorothioate oligonucleotide has $(n-1)$-centres of asymmetry at phosphorous because each linkage can occur as either the $\mathrm{Rp}$ - of Sp-diastereomer (Benimetskaya et al, 1995). Phosphorothioate oligonucleotides used in this experiment contained a random mixture of diastereomers that would have a variety of three-dimensional structure. Benimetskaya et al (1995) reported that binding of phosphorothioate oligonucleotides to basic fibroblast growth factor, recombinant soluble CD4, laminin and fibronectin is P-chirality independent. It is unknown what effect the three-dimensional structure may have on the interactions of phosphorothioate oligonucleotides with DNA-PK.

Both S-oligos and suramin inhibit the binding of HIV-1 gp120 to CD40 and the enzyme activity of DNA polymerases, RNase $\mathrm{H}$ and HIV-1 integrase (Gao et al, 1989, 1992; Stein et al, 1991, 1993; Tramontano et al, 1998). All of these function and enzymes are related to HIV-1 infection and integration into host DNA. Recently, DNA-PK was reported to be involved in the retroviral integration into host DNA (Daniel et al, 1999). S-oligos and suramin will be potent anti-HIV-1 agents. In addition, it is interesting that most of the steps of HIV-1 integration into the host DNA are inhibited by $\mathrm{S}$-oligos and suramin.

The mechanisms of DNA-PK inactivation by S-oligos and suramin are not known. Hammarsten and Chu (1998) reported that single-stranded DNA (ssDNA) did not inhibit the binding of dsDNA to $\mathrm{Ku}$ but it inhibits the binding of dsDNA to DNA-PK. The structure of DNA-PK was revealed by electron crystallography

\section{REFERENCES}

Agrawal S, Goodchild J, Civeira MP, Thornton AH, Sarin PS, Zamecnik PC (1988) Oligodeoxynucleoside phosphoramidates and phosphorothioates as inhibitors of human immunodeficiency virus. Proc Natl Acad Sci USA 85: $7079-7083$

Benimetskaya L, Loike JD, Khaled Z, Loike G, Silverstein SC, Cao L, el Khoury J, Cai TQ, Stein CA (1997) Mac-1 (CD11b/CD18) is an oligodeoxynucleotide-binding protein. Nat Med 3: 414-420

Benimetskaya L, Tonkinson JL, Koziolkiewicz M, Karwowski B, Guga P, Zeltser R, Stec W, Stein CA (1995) Binding of phosphorothioate oligodeoxynucleotides to basic fibroblast growth factor, recombinant soluble CD4, laminin and fibronectin is P-chirality independent. Nucleic Acids Res 23: $4239-4245$

Bojanowski K, Lelievre S, Markovits J, Couprie J, Jacquemin-Sablon A, Larsen AK (1992) Suramin is an inhibitor of DNA topoisomerase II in vitro and in Chinese hamster fibrosarcoma cells. Proc Natl Acad Sci USA 89: $3025-$ 3029

Chiu CY, Cary RB, Chen DJ, Peterson SR, Stewart PL (1998) Cryo-EM imaging of the catalytic subunit of the DNA-dependent protein kinase. $J$ Mol Biol 284: 1075-1081

Coffey Jr RJ, Leof EB, Shipley GD, Moses HL (1987) Suramin inhibition of growth factor receptor binding and mitogenicity in AKR-2B cells. J Cell Physiol 132: $143-148$

Daniel R, Katz RA, Skalka AM (1999) A role for DNA-PK in retroviral DNA integration. Science 284: 644-647

Dignam JD, Lebovitz RM, Roeder RG (1983) Accurate transcription initiation by RNA polymerase II in a soluble extract from isolated mammalian nuclei. Nucleic Acids Res 11: 1475-1489

Gao WY, Han FS, Storm C, Egan W, Cheng YC (1992) Phosphorothioate oligonucleotides are inhibitors of human DNA polymerases and RNase H: implications for antisense technology. Mol Pharmacol 41: 223-229

Gao WY, Stein CA, Cohen JS, Dutschman GE, Cheng YC (1989) Effect of phosphorothioate homo-oligodeoxynucleotides on herpes simplex virus type 2-induced DNA polymerase. J Biol Chem 264: 11521-11526
(Chiu et al, 1998; Leuther et al, 1999). Chiu et al (1998) reported that DNA-PKcs protein has an open, cage-like structure, which may allow the insertion of two DNA ends from the two opposing faces of the protein. Leuther et al (1999) reported that structure of DNA-PKcs protein contains an open channel, similar to those seen in other double-stranded DNA-binding proteins, and a cavity which is large enough to accommodate ssDNA. They suggest that ssDNA binds to the enclosed cavity and inhibit DNA-PK activity. These reports suggest that ssDNA binds to DNA-PK at a position different from where dsDNA binds to DNA-PK. In the present study, we reported that inhibition of DNA-PK activity by S-oligos is not competitive with dsDNA, suggesting that the binding position of S-oligos is different from that of dsDNA. Further experiments are required to elucidate this point.

Cells lacking DNA-PK activity due to defects in DNA-PK components show hypersensitivity to ionising radiation because of an important role of DNA-PK in the repair of DNA doublestrand breaks (Jeggo et al, 1995). A phosphatidylinositol 3-kinase (PI3-kinase) inhibitor, wortmannin, inhibits DNA-PK activity, DSBs repair and sensitises cells to ionising radiation (Rosenzweig et al, 1997; Hosoi et al, 1998b). Suramin is reported to be located in the nucleus of cells exposed to suramin (Bojanowski et al, 1992). In the present study, we demonstrated that suramin suppressed DNA-PK activity and DSBs repair in vivo. Our present observations suggest that suramin may possibly result in sensitisation of cells to ionising radiation by inactivation of DNA-PK and the impairment of DSBs repair.

\section{ACKNOWLEDGEMENTS}

We thank Ms Ikuno Suzuki for technical assistance.
Guvakova MA, Yakubov LA, Vlodavsky I, Tonkinson JL, Stein CA (1995) Phosphorothioate oligodeoxynucleotides bind to basic fibroblast growth factor, inhibit its binding to cell surface receptors, and remove it from low affinity binding sites on extracellular matrix. J Biol Chem 270: $2620-2627$

Hammarsten O, Chu G (1998) DNA-dependent protein kinase: DNA binding and activation in the absence of Ku. Proc Natl Acad Sci USA 95: 525-530

Hosang M (1985) Suramin binds to platelet-derived growth factor and inhibits its biological activity. J Cell Biochem 29: 265-273

Hosoi Y, Kawamura M, Ido T, Takai Y, Ishii K, Nemoto K, Ono T, Kimura S, Sakamoto K (1998a) Sensitization of cells to ionizing radiation by chlorin e6Na. Radiat Oncol Inv 6: $151-156$

Hosoi Y, Miyachi H, Matsumoto Y, Ikehata H, Komura J, Ishii K, Zhao HJ, Yoshida M, Takai Y, Yamada S, Suzuki N, Ono T (1998b) A phosphatidylinositol 3-kinase inhibitor wortmannin induces radioresistant DNA synthesis and sensitizes cells to bleomycin and ionizing radiation. Int $J$ Cancer 78: $642-647$

Jeggo PA, Taccioli GE, Jackson SP (1995) Menage a trois: double strand break repair, V(D)J recombination and DNA-PK. Bioessays 17: 949-957

Lees-Miller SP, Anderson CW (1991) The DNA-activated protein kinase, DNA-PK: a potential coordinator of nuclear events. Cancer Cells 3: $341-346$

Leuther KK, Hammarsten O, Kornberg RD, Chu G (1999) Structure of DNAdependent protein kinase: implications for its regulation by DNA. EMBO J 18: $1114-1123$

Longo JA, Nevaldine B, Longo SL, Winfield JA, Hahn PJ (1997) An assay for quantifying DNA Double-strand break repair that is suitable for small numbers of unlabeled cells. Radiat Res 147: 35-40

Mahoney CW, Azzi A, Huang K-P (1990) Effects of suramin, an anti-human immunodeficiency virus reverse transcriptase agent, on protein kinase $\mathrm{C}$. J Biol Chem 265: 5424-5428 
Marshall WS, Beaton G, Stein CA, Matsukura M, Caruthers MH (1992) Inhibition of human immunodeficiency virus activity by phosphorodithioate oligodeoxycytidine. Proc Natl Acad Sci USA 89: 6265-6269

Matsukura M, Shinozuka K, Zon G, Mitsuya H, Reitz M, Cohen JS, Broder S (1987) Phosphorothioate analogs of oligodeoxynucleotides: inhibitors of replication and cytopathic effects of human immunodeficiency virus. Proc Natl Acad Sci USA 84: 7706-7710

Matsumoto Y, Suzuki N, Sakai N, Morimatsu A, Hirano K, Murofushi H (1997) A possible mechanism for hyperthermic radiosensitization mediated through hyperthermic lability of Ku subunits in DNA-dependent protein kinase. Biochem Biophys Res Commun 234: 568-572

Mitsuya H, Popovic M, Yarchoan R, Matsushita S, Gallo RC, Broder S (1984) Suramin protection of $\mathrm{T}$ cells in vitro against infectivity and cytopathic effect of HTLV-III. Science 226: $172-174$

Murnane JP (1986) Inducible gene expression by DNA rearrangements in human cells. Mol Cell Biol 6: $549-558$

Okayasu R, Suetomi K, Ullrich RL (1998) Wortmannin inhibits repair of DNA double-strand breaks in irradiated normal human cells. Radiat Res 149: $440-445$

Rosenzweig KE, Youmell MB, Palayoor ST, Price BD (1997) Radiosensitization of human tumor cells by the phosphatidylinositol3-kinase inhibitors wortmannin and LY294002 correlates with inhibition of DNA-dependent protein kinase and prolonged G2-M delay. Clin Canc Res 3: 1149-1156

Spigelman Z, Dowers A, Kennedy S, DiSorbo D, O’Brien M, Barr R, McCaffrey R (1987) Antiproliferative effects of suramin on lymphoid cells. Cancer Res 47: $4694-4698$
Stein CA, Neckers LM, Nair BC, Mumbauer S, Hoke G, Pal R (1991) Phosphorothioate oligodeoxycytidine interferes with binding of HIV-1 gp120 to CD4. J Acquir Immune Defic Syndr 4: 686-693

Stein CA, Tonkinson JL, Zhang LM, Yakubov L, Gervasoni J, Taub R, Rotenberg SA (1993) Dynamics of the internalization of phosphodiester oligodeoxynucleotides in HL60 cells. Biochemistry 32: 4855-4861

Stein CA (1993) Suramin: a novel antineoplastic agent with multiple potential mechanisms of action. Cancer Res 53: 2239-2248

Stein CA (1995) Does antisense exist?. Nat Med 1: 1119-1121

Tramontano E, Colla PL, Cheng YC (1998) Biochemical characterization of the HIV-1 integrase 3 '-processing activity and its inhibition by phosphorothioate oligonucleotides. Biochemistry 37: 7237-7243

Wagner RW (1995) The state of the art in antisense research. Nat Med 1: $1116-1118$

Wang H, Zehg Z-C, Bui T-A, DiBiase SJ, Qin W, Xia F, Powell SN, Iliakis G (2001) Nonhomologous end-joining of ionizing radiation-induced DNA double-stranded breaks in human tumor cells deficient in BRCA1 or BRCA2. Cancer Res 61: 270-277

Yakubov L, Khaled Z, Zhang LM, Truneh A, Vlassov V, Stein CA (1993) Oligodeoxynucleotides interact with recombinant CD4 at multiple sites. J Biol Chem 268: 18818 - 18823

Zugmaier G, Lippman ME, Wellstein A (1992) Inhibition by pentosan polysulfate (PPS) of heparin-binding growth factors released from tumor cells and blockage by PPS of tumor growth in animals. J Natl Cancer Inst 84: $1716-1724$ 